\title{
ONTWIKKELING VAN DIE GEMENEREG IN DIE LIG VAN ARTIKELS 39(2) EN 173 VAN DIE GRONDWET ${ }^{1}$
}

Regter LTC Harms

Die onderwerp van hierdie voordrag is wydlopend en voortydig. Toe Professor Wigmore in 1914 met 'n vergelykbare onderwerp genader is, het hy wyslik die aanbod van die hand gewys: ${ }^{2}$

The law is so obviously in a seething change that one might as well expect to analyze a chemical reaction while the test tube is over the flame.

Oor deliktereg (law of torts) het hy bygevoeg:

The old-time doctrines of liability are changing so fast that it is difficult to keep up with them . . . certainly many existing books may be sold for old paper.

'n Mens kan met reg vra of die ius connubiorum van Brouwer en die Law of Husband and Wife van Professor Hahlo nie nou "Seksuele Verhoudingsreg" geword het nie. Is onregmatigheid en skuld vereistes vir deliktuele aanspreeklikheid of hang dit maar daarvan af of die verweerder die staat is of versekering dra? Leer u nog steeds u studente dat 'n kontrak 'n tweesydige verbintenis is? Dit is mos ' $n$ losse driesydige verhouding waartoe die regter ' $n$ party is? Leer $u$ hulle steeds dat dit op wilsooreenstemming gebaseer is in plaas van willekeur? Die verkorte LLB kan dan nog meer verkort word.

1 FW de Klerk Gedenklesing, 12 Oktober 2004, Noordwes-Universiteit (Potchefstroom Kampus). Grondwet van die Republiek van Suid-Afrika, 1996 (hierna die Grondwet of Handves).

2 Aangehaal deur Tony Martino Famous Trade Marks, cf Martino Trademark dilution. 
Die Grondwet se uitgangspunt is dat die bestaande regsorde grootliks behoue bly, tot die argwaan van sommige. Selfs die regbank het tot tyd en wyl behoue gebly, tot die irritasie van sommige. Of is dit van vele? Die gemenereg - oftewel nie-statutêre reg - het sy posisie behou. Daar is egter een belangrike kwalifikasie: hoër howe het kragtens artikel 173 die bevoegdheid om die gemenereg te ontwikkel met inagneming van geregtigheid; en dit moet geskied deur die "spirit, purport and objects" ("gees, strekking en oogmerke") van die Handves te bevorder (artikel 39(2)). Eintlik is dit meer as ' $n$ bevoegdheid, dit is ' $n$ verpligting maar daar dien op gelet te word dat artikel 173 nie verskans is nie terwyl artikel 39(2) wel is - ietwat van 'n teenstrydigheid.

Die Kanadese grondwet is anders en bevat nie ' $n$ soortgelyke bepaling nie. Desondanks ag die howe daar dit hulle plig om die gemenereg in ooreenstemming met hulle Handves te bring. ${ }^{3}$

Oorbekend is die woorde van Lord Tomlin in Pearl Assurance ${ }^{4}$ dat die RomeinsHollandse regstelsel -

is a virile living system of law, ever seeking, as every system must, to adapt itself consistently with its inherent basic principles to deal effectively with the increasing complexities of modern organised society.

Van oudsher het ons howe hulself die bevoegdheid toegeëien om die gemenereg te ontwikkel. Volgens De Groot 1.2.22 het dit deel van die regterlike eed gevorm dat regters, wanneer daar ' $n$ tekortkoming in die reg is, ' $n$ beslissing ooreenkomstig hulle beste rede, kennis en "bescheidenheid" moet lewer. ${ }^{5}$ En altyd het ons howe aanvaar dat dit nie alleen sake soos handelsbehoeftes is wat 'n regsontwikkeling dryf nie maar veral die boni mores, die goeie sedes, die gemeenskapsgevoel. Die Handves is natuurlik by uitstek 'n bron of samevatting van die gemeenskapsgevoel, van wat reg en billik is. In beginsel dus (selfs

3 Dagenais v Canadian Broadcasting Corp 25 CRR 2d 27 (SCC).

4 Pearl Assurance Co Ltd v Union Government 1934 AD 560 (Geheime Raad) 563.

5 Sien vir besonderhede Hahlo en Kahn SA Legal System and its Background 304. 
sonder die betrokke voorskrif) sou dit die maatstaf vir enige regsontwikkeling moes wees - net soos dit ook die maatstaf vir wetgewing daarstel.

Hierdie aspek kan aan die hand van twee uitsprake geïllustreer word. Oorbekend is Minister van Justisie $v$ Ewels. ${ }^{6}$ Volgens oorlewering het die hoofregter die advokate vir die gebrek aan gesag in hulle betoog verwyt. En toe: in een sin, sonder gesag, skep hy 'n onregmatigheidskriterium. Meer onlangs was Bogoshi ${ }^{7}$ waar dit om die aanspreeklikheid vir laster van die media gegaan het. Daar het die hof op grond van beleidsoorwegings ' $n$ beginselbesluit geneem om bestaande gesag omver te werp deur groter waarde aan die gemeenregtelike beginsel van vryheid van spraak te heg en die pers se aanspreeklikheid af te water. Hoewel nie op die Handves gebaseer nie, het Bogoshi later die handvestoets geslaag. ${ }^{8}$

Die regsontwikkeling het dikwels onder die dekmantel van petere fontes, oftewel terugkeer na die gemeenregtelike bronne, plaasgevind. Dit het geweldig baie vir die ontwikkeling van 'n wetenskaplike benadering tot die reg beteken. Sistematisering het die reg nog nooit kwaad gedoen nie. Soms egter was daar oorsistematisering veral deur die aanvaarding van akademici wat die gemenereg deur ' $n$ pandektisties-germanistiese bril gelees het (en vergeet het dat die naelstring wat ons aan die Europese Vasteland verbind het, deur die Engelse reeds in 1806 geknip is). As voorbeeld geld die begrip van wederregtelikheidsbewussyn. Die actio iniuriarum het in die algemeen nie so 'n vereiste nie. Sien byvoorbeeld aanranding en onregmatige aanhouding. Maar toe word wederregtelikheids-bewussyn in 1959 by laster ingesleep, iets wat mettertyd tot allerlei kunsgrepe aanleiding gegee het. As eenmaal aanvaar word dat animus iniuriandi die opset om te benadeel beteken, wat het mens meer nodig? Die begrip is sonder die Grondwet in ons reg ingevoer en kan daarsonder

6 Minister van Justisie $v$ Ewels 1975 (3) SA 590 (A).

7 National Media Ltd v Bogoshi 1998 (4) SA 1196 (HHA).

8 Khumalo v Holomisa 2002 (5) SA 401 (KH). 
weer uitgevoer word. Maar dan wou iemand die Hoogste Hof van Appèl omverwerp, en daarvoor het hy die Handves nodig gehad. ${ }^{9}$

Die Pearl Assurance-bevoegdheid het ingeboude beperkings. Grondliggend is steeds die ius dicere non facere-beginsel. Aanpassings kan alleen "consistently with its inherent basic principles" geskied. Howe is ook nie geneig om maklik erkenning aan veranderde mores te verleen nie. ' $n$ Geleidelike verandering en nie ' $n$ radikale verandering nie, is geoorloof.

Dit word maklik oor die hoof gesien dat die Pearl Assurance-bevoegdheid steeds bestaan, met ander woorde, howe het nog steeds die bevoegdheid om die reg aan te pas om aan handels- en ander behoeftes ter voldoen al hou die aanpassing nie met die Handves verband nie.

Hoewel dit dikwels veronderstel word dat die onderliggende beginsels van die gemenereg in stryd met die Handves is, is die premisse vals. Die RomeinsHollandse reg het byvoorbeeld nie ' $n$ onderskeid op grond van ras getref nie. Dat ras 'n persoon se status kon beïnvloed, was 'n latere uitvindsel van die Volkereg wat met kolonisasie verband gehou het en 'n regverdigingsgrond om ander se grond en goed af te neem, geskep het. Maar dan was dit nie ras per se nie. Die beskawing van 'n stam of volk het afgehang van die feit of hulle gekersten was al dan nie. Die eerste uitsondering (benewens Jode) was die Turke: vanweë toenemende handel is hulle te spyte van hulle geloof teen die middel van die $19 \mathrm{e}$ eeu tot beskaafdes deur die Volkereg - 'n Westerse uitvinding - verhef. Maar binne die Christendom en selfs binne die Protestantedom was daar van tyd tot tyd diskriminasie op grond van geloof en ook 'n gebrek aan gewetensvryheid, iets wat Hugo de Groot aan sy lyf en Van Oldenbarneveld aan sy nek ervaar het.

9 Heyns v Venter 2004 (3) SA 200 (T). 
"The common law was ... fundamentally affected by the cancer of apartheid," beweer Dennis Davis. ${ }^{10}$ As enigste voorbeeld gee hy die beginsel van absolute aanspreeklikheid van die pers vir laster wat deur Bogoshi omvergewerp is. Die sake wat absolute aanspreeklikheid van die pers geskep het, was toevallig SAUK $v$ O'Malley, ${ }^{11}$ waar 'n redakteur van 'n nie-regeringsgesinde koerant teen die SAUK geslaag het en Pakendorf $v$ De Flamingh ${ }^{12}$ waar ' $n$ advokaat teen ' $n$ Afrikaanse koerant suksesvol was. Davis het Bogoshi uitgesonder omdat hy iets sinisters daarin gesien het dat die Hoogste Hof van Appèl Bogoshi op gemeenregtelike en nie op grondwetlike gronde nie beslis het. (Bogoshi is nie op die Handves gebaseer is nie omdat 9 van die 10 lasterlike artikels voor 1994 gepubliseer is en die stelling van die Konstitusionele Hof in Du Plessis $v$ De Klerk $^{13}$ dat die Handves nie terugwerkend is nie, letterlik opgeneem is. Sedertdien het die Konstitusionele Hof dit as obiter bestempel en daarvan afgewyk soos later sal blyk.)

In sy regterlike gewaad het r Davis ook al per geleentheid "wolf-wolf" geskreeu. In Geldenhuys ${ }^{14}$ het die eiser na bewering beserings in polisie-aanhouding opgedoen. Om die staat aanspreeklik te stel, het Davis $r$ geoordeel, verg 'n transformasie van ons reg, "shaped by memory of that which lay at the very heartikel of our apartheid past." Soos die Hoogste Hof van Appè ${ }^{15}$ later aangetoon het, die reël wat hy wou skep, het sins 1912 bestaan en is in 1977 bevestig.

Helen Keller is gevra wat erger is as om blind te wees. Haar antwoord: goeie oë waarmee nie gekyk word nie.

10 Davis Democracy and Deliberation 161.

11 SAUK v O'Malley 1977 (3) SA 394 (A).

12 Pakendorf v De Flamingh 1982 (3) SA 146 (A).

13 Du Plessis v De Klerk 1996 (3) SA $850(\mathrm{KH})$.

14 Geldenhuys v Minister of Safety and Security [2002] 3 All SA 82 (K).

15 Minister van Veiligheid en Sekuriteit v Geldenhuys 2001 (4) SA 515 (HHA) par 24-25. 
Natuurlik is die Romeins-Hollandse reg of die gemenereg nie deurgaans in ooreenstemming met die Handves nie. ' $n$ Voorbeeld is die ongelyke status van mans en vrouens. Eietydse norme en waardes het noodwendig neerslag in die reg gevind want die reg weerspieël die gemeenskapswaardes van 'n bepaalde tydperk. Soos Oliver Wendell Holmes gesê het,

The life of the law has not been logic; it has been experience. The felt necessities of the time, the prevalent moral and political theories, intuitions of public policy, avowed or unconscious, even the prejudices which judges share with their fellowmen, have had a good deal more to do than the syllogism in determining the rules by which men should be governed. ${ }^{16}$

Interessant is gemeenregtelike misdade. Benewens sodomie en miskien godslaster is daar weining, indien enigiets, wat nie in ooreenstemming met die Handves is nie. ${ }^{17}$ Die gemenereg het ook, behalwe vir strafbare manslag, altyd opset as skuldvorm vereis. Skuldlose aanspreeklikheid is 'n skepping van moderne wetgewers. Opmerklik ook is die feit dat die beginsel van gemeenskaplike doel, veral soos verwoord in $S v$ Safatsa, ${ }^{18}$ nie in stryd met die Handves is nie. ${ }^{19}$

Die Strafproseswet van 1977 illustreer 'n parallel. Afgesien van enkele aspekte soos die doodstraf en lyfstraf - wat in ieder geval die wense van die kiesers verteenwoordig het - is daar min in die wet wat in stryd met die Handves is. Die destydse Minister van Justisie het dit nie geglo nie en het in 1994 die Regskommissie opdrag gegee om die wet in hierdie opsig dringend en indringend na te gaan. Dit is gedoen maar die aspekte wat na vore getree het, is

16 Holmes Common Law 5. Vgl Voet 1.1.8.

17 Oor bestialiteit: S v M 2004 (3) SA 680 (O).

$18 S v$ Safatsa 1988 (1) SA 868 (A).

19 S v Thebus 2003 (6) SA $505(\mathrm{KH})$. 
oënskynlik so onbenullig dat die wetgewer die wet tot dusver onveranderd gelaat het. $^{20}$

Daar is ' $n$ logiese en beginselverskil tussen die "ontwikkeling" van ' $n$ gemeenregtelike reël in ooreenstemming met grondwetlike norme en die "ongeldigverklaring" van 'n reël wat in stryd daarmee is. Soos blyk uit die bespreking wat volg, tref howe nie die onderskeid nie. Inderdaad beskou die Konstiusionele Hof beide as gevalle van "ontwikkeling". ${ }^{21}$

'n Voorbeeld van ongeldigverklaring is die reël waarvolgens 'n huweliksooreenkoms tussen partye tot ' $n$ potensieel poligame huwelik in stryd met die openbare orde is. Die reël is in 1983 deur die Appèlhof bevestig. ${ }^{22}$ In Ryland $v$ Edros $^{23}$ is die Kaapse hof versoek om van die reël af te wyk. Die vraag is soos volg geformuleer:

Can it be said, since the coming into operation of the new Constitution, that a contract concluded by parties which arises from a marriage relationship entered into by them in accordance with the rites of their religion and which as a fact is monogamous is 'contrary to the accepted customs and usages which are regarded as morally binding upon all members of our society' or is 'fundamentally opposed to our principles and institutions'?

Die hof het toe bevind dat die reël onversoenbaar is met die gelykheidsbeginsel in die nuwe grondwetlike bedeling vervat omdat sy bestaan afhanklik was van die waardenorme van 'n bepaalde geloofsgroep. Streng gesproke was dit nie 'n geval van ontwikkeling van die gemenereg nie maar van ongeldigverklaring van 'n reël. Wat myns insiens nie verduidelik word nie, is hoe die interim Grondwet 'n ooreenkoms wat in 1977 gesluit is - onthou dat die Appèlhof in 1983 beslis het dat die ooreenkoms ongeldig is - geldig kon maak.

20 SALR Application of the Bill of Rights.

$21 S v$ Thebus supra par 28.

22 Ismail v Ismail 1983 (1) SA 1006 (A).

23 Ryland v Edros 1997 (2) SA 690 (C). 
Dat die Handves onnodig was om die resultaat in Edros te bereik, blyk uit Amod. ${ }^{24}$ Die weduwee uit 'n Moslem huwelik het ' $n$ eis ingestel vir verlies aan onderhoud vanweë haar man se dood gedurende 1993. Grondwetlike waardes was daar nog nie. Volgens geldende reg, gebaseer op Christelike norme, het die oorledene geen regsplig gehad om haar te onderhou nie. ${ }^{25}$ Die Hoogste Hof van Appèl het in Amod op 'n nuwe etos "of tolerance, pluralism and religious freedom" staatgemaak wat glo reeds voor 1994 sy beslag gekry het om te bevind dat die boni mores verander het.

Met die beredenering kan gekibbel word. Die regsplig van 'n Moslem man om sy vrou te onderhou, vind die Hoogste Hof van Appèl in Edros ten spyte daarvan dat Edros op die interim Grondwet gebaseer was. Edros word dan teruggeprojekteer en op 'n pre-grondwetlike periode toegepas. Daarbenewens, waar die nuwe etos nie alleen godsdiensvryheid nie, maar ook gewetensvryheid voorstaan, verg die Hoogste Hof van Appèl in Amod as voorvereiste vir die geldigheid van so 'n eis dat die onderhoudsplig ontstaan het uit "a solemn marriage in accordance with the tenets of recognised and accepted faith". Hierdie vereiste val vreemd op die oor in 'n sekulêre staat. ${ }^{26}$

Interessant is die Konstitusionele Hof se benadering in $\mathrm{Amod}^{27}$

The Supreme Court of Appeal has always had an inherent jurisdiction to develop the common law to meet the needs of a changing society. The circumstances in which it elects to do so and the manner in which it develops the law form partikel of this jurisdiction. With the coming into force of the interim Constitution, and later the 1996 Constitution, this power must now be exercised in accordance with the "spirit, purport and objects" of the Bill of Rights.

In my view, the vesting of the power in the Supreme Court of Appeal ... to develop the common law necessarily includes the jurisdiction to decide

24 Amod v Multilateral Motor Vehicle Accidents Fund [1999] 4 All SA 421 (A).

25 Suid-Afrikaanse Nasionale Trust en Assuransie Maatskappy Bpk v Fondo 1960 (2) SA 467 (A). Terloops, nadat die Appèlafdeling dit beslis het, het die wetgewer tav lobolaverbintenisse die posisie reggestel, maar getrou aan die tydsvak slegs ten gunste van die weduwee. Algemene Regswysigingswet 76 van 1963 a 31.

26 Vgl egter Robinson v Volkes NO 20042 All SA 61 (C).

27 Amod v Multilateral Motor Vehicle Accidents Fund 1998 (4) SA $753(\mathrm{KH})$. 
whether the power can be exercised in cases in which the cause of action arose before the Constitutions were in force, or whether it should be confined to causes of action arising after the coming into force of such Constitutions.

As die parlement ' $n$ wet aanneem, is die vermoede dat dit nie terugwerkend of van toepassing op hangende gedinge is nie. Regters moet kies, maar op grond waarvan kan die keuse uitgeoefen word? Die antwoord word gelukkig, soos die jare voortsnel, geleidelik irrelevant.

As die onderskeid tussen "ontwikkeling" en "ongeldigheid" behoorlik voor oë gehou is, sou die gespartel onnodig gewees het: die betrokke gemeenregtelike reël was sedert 1994 ongeldig; ' $n$ party behoort hom nie te kan verweer op 'n reël wat nie deur die bestaande regsorde gedoog word nie.

Die versuim om tussen ontwikkeling en ongeldigverklaring te onderskei, gaan nog by howe spook en tot verdere denkfoute lei. "Ontwikkeling" veronderstel 'n geleidelike aanpassing soos onder Pearl Assurance. Maar wat gaan gebeur as die gemeenregtelike reël ongeldig verklaar word en iets heel nuuts in die plek gestel moet word; en daar opsies is met vergelykbare waardes? Het die howe die reg om te kies? Het die howe die bevoegdheid om 'n ongeldigverklaring op te skort? Kan die howe voorskriftelik vir die wetgewer wees?

Daar is diegene wat glo dat die gemenereg perfek is en dat die gemenereg nie deur die Handves beïnvloed is nie. Hulle is eenvoudig verkeerd. Aan die ander kant van die spektrum is daar natuurlik diegene wat glo dat die Handves 'n jaglisensie aan die regbank verleen en dat die gemenereg voëlvry verklaar is. Regters mag skielik sake na willekeur besleg. Die positiewe reg word ' $n$ saak van regterlike diskresie. Omdat ek nie van die actio quanti minoris hou nie, is dit 
ongrondwetlik. ${ }^{28}$ Bloot omdat ek ' $n$ regter is, kan ek die demokatiese bestel omseil en die parlement irrelevant maak. ${ }^{29}$ Maklik word die waarskuwing van die Konstitusionele Hof vergeet: ${ }^{30}$

In exercising their powers to develop the common law, Judges should be mindful of the fact that the major engine for law reform should be the Legislature and not the Judiciary. In this regard it is worth repeating the dictum of lacobucci J in $E R v$ Salituro, which was cited by Kentridge AJ in Du Plessis v De Klerk:

Judges can and should adapt the common law to reflect the changing social, moral and economic fabric of the country. Judges should not be quick to perpetuate rules whose social foundation has long since disappeared. Nonetheless there are significant constraints on the power of the Judiciary to change the law. ... In a constitutional democracy such as ours it is the Legislature and not the courts which has the major responsibility for law reform. ... The Judiciary should confine itself to those incremental changes which are necessary to keep the common law in step with the dynamic and evolving fabric of our society.

In die VSA word gewoonlik 'n onderskeid getref tussen liberale regters (synde regters wat reg skep) en konserwatiewe regters (diegene wat die reg uitlê). Statisties is bewys dat dat die liberales byna deur die bank lede van die Demokratiese Party is terwyl konserwatiewes lede van die Republikeinse Party.

'n Analoë verskynsel glo ek sal mens moeilik in Suid-Afrika vind. 'n Statistiese analise, byvoorbeeld, van die uitsprake van die Appèlhof sedert 1950 (wat veronderstel het dat al wat 'n Afrikaanse van gehad het, 'n ondersteuner van die NP was) kon geen duidelike tendens bepaal nie. ${ }^{31}$ By ons is daar myns insiens nie ' $n$ verband tussen politieke/persoonlike konserwatisme en regskonserwatisme nie; en ook nie tussen persoonlike "liberalisme" (as ek die woord wat sy betekenis verloor het, mag gebruik) en "regsliberalisme" nie.

28 Janse van Rensburg v Grieve Trust 2000 (1) SA 315 (K).

29 Sien Bork Tempting of America vir ' $n$ volledige behandeling van die problematiek wat nie uniek aan 'n nuwe demokrasie is nie.

30 Carmichele $v$ Minister of Safety and Security 2001 (4) SA $938(\mathrm{KH})$ par 36.

31 Haynie Judging Black and White. 
'n Engelse regter het onlangs verklaar dat -

the courts are not a branch of social services whose job is to help the infirm or the unwise and the Protocol (lees: die Grondwet) does not require them to do so. ${ }^{32}$

Die tweede amorfe groep stem nie hiermee saam nie. Volgens hulle geld ook stare decisis en die presedente-stelsel nie meer nie. In Walters het 'n enkel regter byvoorbeeld geweier om ' $n$ bevinding van die Hoogste Hof van Appèl dat ' $n$ bepaling in die Strafproseswet grondwetlik is, te aanvaar en moes die Konstitusionele Hof hom tot orde roep. ${ }^{33}$

High courts are obliged to follow legal interpretations of the SCA, whether they relate to constitutional issues or to other issues, and remain so obliged unless and until the SCA itself decides otherwise or this Court does so in respect of a constitutional issue. It should be made plain, however, that this partikel of the judgment does not deal with the binding effect of decisions of higher tribunals given before the constitutional era. 34

Ten spyte hiervan is daar nog hooggeregshofregters wat die Hoogste Hof van Appèl kort-kort op sy plek sit - partymaal sonder 'n beroep op grondwetlike waardes ${ }^{35}$ - en hulle eie sienings oor wat die reg moet wees, wil afdruk.

' $n$ Voorbeeld bied die uitspraak van die Hoogste Hof van Appèl in Jayija. ${ }^{36}$ Die vraag wat ontstaan het, is of ' $n$ openbare amptenaar gevange geset kan word op grond van minagting van die hof indien hy nie 'n geldvonnis teen die staat voldoen nie. Die gemeenregtelike beginsel is dat ' $n$ versuim om ' $n$ vonnisskuld te betaal, nie ' $n$ misdryf is nie. Maar dan is daar ook die statutêre beginsel dat daar nie op die staat se bates beslag gelê mag word ter uitvoering van 'n vonnis nie.

32 Laddie $r$ in Merck $v$ Generics [2003] EWHC 2842 (Pat).

33 Bv bespreek in Ex parte Minister of Safety and Security: In re S v Walters 2002 (4) SA 613 (KH) par 55 ev.

34 Sien verder Afrox Healthcare Bpk v Strydom 2002 (6) SA 21 (HHA) par 30.

35 As diesulkes oor die vingers geraps word, moet hulle nie verbaas wees nie: Blaauwberg Meat Wholesalers v Anglo Dutch Meats (Exports) 2004 (3) SA 130 (HHA) par 20.

36 Jayija v MEC for Welfare [2003] 2 All SA 223 (HHA); 2004 (2) SA 611 (HHA). 
Die besondere provinsiale minister het nie die vonnisskuld in die neergelegde tyd betaal nie. Die probleem waarvoor die howe gestel is, is hoe om die staat tot verantwoording te roep om sy grondwetlike verpligtinge na te kom. Provinsiale howe het toe bevind dat die verantwoordelike minister of amptenaar gevange geset kan word en dat hierdie ontwikkeling van die gemenereg nodig is om aan die Grondwet tande te gee.

Wat egter nie oorweeg is nie, is die legaliteitsbeginsel. Dit beteken onder meer dat 'n hof nie 'n misdryf mag skep nie (die ius acceptum-beginsel). ${ }^{37}$ Aan die hand hiervan het die Hoogste Hof van Appèl beslis dat die provinsiale howe gefouteer het om die misdaadsomskrywing van minagting van die hof uit te brei. Dit het egter nie 'n provinsiale regter verhoed om die Hoogste Hof van Appèl se uitspraak omver te werp nie want, het hy gesê, hy is slegs aan die Grondwet (bedoelende sy uitleg daarvan) onderhewig. "The rule of law" is die towerspreuk. Asof die legaliteitsbeginsel nie deel van die "rule of law" is nie; asof die presedentestelsel nie deel daarvan is nie; en asof die Konstitusionele Hof nie volgens die Grondwet die finale arbiter van sy betekenis is nie. Tevergeefs Walters, tevergeefs. Maar dan was die Sunday Times heel opgewonde oor die uitspraak.

Daar is ook diegene wat veronderstel dat die Handves absolute waardes daarstel en dat ' $n$ afweging van waardes nie veroorloof is nie. Afrox Health Care $v$ $S_{\text {Strydom }}^{38}$ bied 'n nuttige illustrasie. Die eiser moes 'n operasie ondergaan. Hy het ' $n$ bepaalde private hospitaal gekies. Dit was nie ' $n$ noodgeval nie. Hy onderteken 'n vrywaringsvorm wat die hospitaal vrywaar teen aanspreeklikheid vir nalatigheid. ' $n$ Verpleegster het toe na bewering sy been verkeerd verbind en dit het komplikasies veroorsaak wat glo twee miljoen Rand se skade veroorsaak het. Sy saak was dat die vrywaringsklousule hom nie bind nie omdat dit in stryd met die "gees, strekking en oogmerk" van artikel 27(1)(a) van die Grondwet is.

37 Snyman Strafreg $36-37$.

38 N 34. 
Hierdie bepaling, wat voorsiening maak vir die reg 'to access to health care services', is waarskynlik een wat 'n reg teenoor die staat skep en nie teenoor private instansies nie. Hoe dit ook al sy, as die reg onbegrens is, sou die privaat hospitaal natuurlik dienste gratis moes verskaf. Aangesien die Handves dus nie die stel van voorwaardes vir die verskaffing van mediese dienste verbied nie, is die vraag of die besondere bepaling in die konteks van die verskaffing van private mediese dienste teen die openbare belang is. Dit is ' $n$ algemeen geldende vraag waarmee howe hulle van oudsher besig gehou het. Die Hoogste Hof van Appèl het, terloops, bevind dat dit nie teen die openbare belang is nie.

Hieroor is die hof gekritiseer. ${ }^{39}$ Skrywers was in sak en as. Hawthorne ${ }^{40}$ skep 'n metafoor:

... which could have been mapped out in an Argentinian dance hall, so much it resembles a tango. The nimble little blind dancer, Justice, manages a tentative step forward once in a while only to be brutally reversed the length of the floor by her big, brutish partner, Business. Gliding along the floor she is subjected to a repetitive monologue, condemning her hopes and dreams as naïve and out of touch with reality.

Dat die reg op mediese dienste nie onbegrens is nie, is toevallig deur die Konstitusionele Hof beslis in ' $n$ heelwat dramatieser geval. ${ }^{41}$ ' $n$ Nierlyer wat daagliks nierdialise benodig het om te kon oorleef, kon nie behandeling by die plaaslike hospitaal bekom nie omdat die hospitaal nie die behandeling kon bekostig nie. Die pasiënt kon nie private behandeling bekostig nie. Die Konstitusionele Hof het sy eis afgewys omdat sy belang teen die groter belang van talle pasiënte wat op behandeling geregtig is, opgeweeg moes word. Hy is vermoedelik sedertdien oorlede.

Wat nie uit die oog verloor moet word nie is wat die Hoogste Hof van Appèl nie in Afrox beslis het nie: dit is veral nie beslis dat alle vrywaringsklousules geldig is nie; of dat staatshospitale geregtig is om daarvan gebruik te maak nie. (Daar was

39 Bv Tladi 2002 SAPR 473.

40 Hawthorne 2004 THRHR 294.

41 Soobramoney $v$ Minister of Health KZN 1998 (1) SA 765 (KH). 
ook geen getuienis dat alle hospitale 'n soortgelyke vereiste gehad het nie; inteendeel, die verweerder se latere toelatingsvorms het nie die vrywaring bevat nie.) Die geval kan met Stott $v$ Johannesburg Country Club and Another ${ }^{42}$ vergelyk word. Mev Stott se man is deur die weerlig op die golfbaan doodgeslaan. Sy beweer dat die klub nalatig was. Hoe dit ook al sy, die klub het op 'n vrywaringsklousule staatgemaak. Die Hoogste Hof van Appèl het op 'n uitlegsbasis bevind dat die klousule nie die klub teen haar eis gevrywaar het nie. Ten besluite het die meerderheid van die hof egter die vraag ge-opper of ' $n$ klousule wat iemand teen nalatige doodsveroorsaking vrywaar, nie teen die openbare belang is nie. Een van die faktore genoem, is die feit dat die Handves ' $n$ besonder hoë waarde aan die reg op lewe heg. Maar dan het die gemenereg dit ook gedoen - die Handves verskans bloot die reg teen ingrype of verwatering.

Hawthorne en sy geesgenote se grief is andersyds dat die Hoogste Hof van Appèl kapitalisties ingestel is en ten gunste van Big Brutish Business beslis. Op hierdie wyse word die Grondwet ondergrawe. As gesag hiervoor word op Brisley $v$ Drotsky ${ }^{43}$ gehamer. Toegegee, die Hoogste Hof van Appèl het ten gunste van kontrakteervryheid bevind maar dit was beswaarlik 'n saak tussen Big Brutish Business en Little Lulu. ${ }^{44}$ Die suksesvolle party was ' $n$ weduwee wat van haar huurinkomste afhanklik was. Die huurder het nie betaal nie en het haar op 'n swetterjoel verwere beroep. Een was dat die kontrak, wat 'n mondelinge wysigingsverbod bevat het, mondeling gewysig is.

Brisley het om die geldigheid van daardie verbod, die "non-variation" klousule, gegaan: die sogenaamde Shifren-beginsel. ${ }^{45}$ Die hof het eenparig bevind dat die beginsel nie omvergewerp moes word nie en dat so 'n klousule geldig is. Die Grondwet het niks met die saak uit te waai nie. Waaroor die hof 4:1 verskil het,

42 Stott $v$ Johannesburg Country Club and Another 2003 (4) SA 559 (T).

43 Brisley v Drotsky 2002 (4) SA 1 (HHA). Verlof tot appèl na die Konstitusionele Hof is geweier.

44 Gevolg in De Villiers v BOE Bank [2004] 2 All SA 457; 2004 (3) SA 1 (HHA), 'n geval van Big Business teen Big Business.

45 SA Sentrale Ko-op v Shifren 1964 (4) SA 760 (A). 
was of die Shifren-klousule se geldigheid afhanklik is van die bona fides van die party wat hom daarop beroep. Dit lei natuurlik tot 'n sirkel-argument want die antwoord moet noodwendigerwys afhanklik wees van die vraag of daar 'n mondelinge wysiging van die kontrak was: as dit gewysig is, is ' $n$ beroep op die klousule mala fide; as dit nie gewysig is nie, is die beroep bona fide.

Die klem op kontraksvryheid lei natuurlik tot ander gevolge en wat vantevore conta bonos mores was, soos "champerty" en "maintenance", is nie meer nie. ${ }^{46}$ In hierdie verband het die verskanste reg op toegang tot howe 'n belangrike rol gespeel. Die mores, soos vervat in die Grondwet, vind dus wel neerslag in die kontraktereg, al glo nie almal dit nie. En bona fides speel steeds ' $n$ belangrike rol in die kontraktereg: dit is egter nie 'n muti wat kontraktuele verpligtingte kan wegtoor nie. ${ }^{47}$

Die gemenereg bestaan uit ' $n$ magdom bepalings wat oor eeue ontwikkel het baie kan tot Moses, Solon of Hammurabi herlei word (om nie Justinianus te vergeet nie) - en is iets waaraan groot geeste hulself gewy het. Die reëls vorm 'n fyn web en 'n gekarring aan een draadjie kan skokgolwe veroorsaak - golwe wat nie voorsien is nie en wat nie gewou is nie. "The law of unexpected consequences" is ongenadig. Duburoro illustreer die aspek. ${ }^{48}$ 'n Provinsiale hof het uit eie beweging bevind dat 'n bepaling in 'n notariële verband wat die skuldeiser daarop geregtig maak om die verpande goed op te eis, ongrondwetlik is. (Prof Susan Scott het heelwat onvleiende opmerkings oor die uitspraak gemaak, maar dit bloot terloops.) Toe die saak in die Hoogste Hof van Appèl geargumenteer is, het die gevolge van die bevinding duidelik geword:

... the appellants were driven to submit that conditional contracts (especially sales), forfeiture clauses, agency agreements permitting the

46 Price Waterhouse Coopers Inc v National Potato Co-op Ltd [2004] 3 All SA 20 (HHA).

47 SA Forestry Co Ltd $v$ York Timbers Ltd (HHA-uitspraak 9 Sep 2004).

48 Bock v Duburoro Investments 2004 (2) SA 242 (HHA) gevolg in Juglal v Shoprite Checkers [2004] 2 All SA 268 (HHA); 2004 (5) SA 258 (HHA). 
sale of one's property, powers of attorney in rem suam, voluntary repossessions and even rights of retention are all unconstitutional.

U sal onthou dat De Groot gesê het dat regters met regsontwikkeling beskeie moet wees. Lord Simon of Glaisdale kon ook beeldspraak gebruik: ${ }^{49}$

(J)udicial advance should be gradual. ... (O)ne step is enough. ... It is, I concede, a less spectacular method of progression than somersaults and cartwheels; but it is the one best suited to the capacity and resources of a Judge.

Die Franse chemikus, Antoine Lavoisier, is in 1794 tydens die Franse revolusie tereggestel. Terwyl die bloed spat, het 'n omstander droog opgemerk:

Dit het 'n paar sekondes gevat om sy kop met 'n guillotine af te kap; dit gaan Frankryk 'n eeu neem om nog so 'n kop te kweek. ${ }^{50}$

Tot dusver het ek Carmichele ${ }^{51}$ vermy maar onvermydelik moet ek daarmee handel. $U$ mag bewus wees van die feit dat ek die laaste in 'n reeks van die uitsprake gelewer het. ${ }^{52}$ Die finale gevolgtrekking - wat die onderwerp onder bespreking betref - is dat die versuim van die staat om in ' $n$ gegewe geval borg teen te staan, wederregtelik kan wees teenoor 'n derde wat voorsienbaar deur die vrygelatene benadeel (aangerand) is. ' $n$ Australiese kollega het na aanleiding hiervan aan my geskryf en gevra: "Is this the end of civilisation as we know it?" My antwoord is gepriviligeerd. Maar dit los nie die probleem van vele om die grondslag van die verrigtinge te verstaan, op nie. Prof Johan van der Walt, ${ }^{53}$ het ' $n$ heel interessante teorie maar laat ek $u$ my siening gee sonder om syne te analiseer.

49 Miliangos v George Frank (Textiles) Ltd 1976 AC 443 (HL) aangehaal in Brisley.

50 Oorvertel deur Huber Liability: The legal revolution and its consequences 33.

51 Carmichele $v$ Minister of Safety and Security 2001 (1) SA 489 (HHA); Carmichele v Minister of Safety and Security 2001 (4) SA $938(\mathrm{KH})$.

52 Minister of Safety and Security v Carmichele 2004 (3) SA 304 (HHA).

53 Van der Walt 2003 SAJHR 517. 
U moet maar die ompad verskoon. Toe die saak die eerste maal voor die Hoogste Hof van Appèl gekom het, het die advokate die hof meegedeel dat daar geen grondwetlike vrae in die saak ontstaan nie. Die hof het daarop bevind dat die eiseres nie 'n prima facie saak van onregmatigheid uitgemaak het nie. Sy het haar toe op die Konstitusionele Hof beroep en aangesien die Konstitusionele Hof slegs grondwetlike vrae mag behandel, het sy natuurlik haar saak op grondwetlike gronde gebaseer. Die Konstitusionele Hof het haar gelyk gegee en die Hoogste Hof van Appèl betig omdat dié versuim het om mero motu die Grondwet by te bring. Die Hoogste Hof van Appèl moes naamlik vasgestel het of die gemenereg nie ontwikkel moet word ooreenkomstig artikel 39(2) nie. Watter reël ontwikkel moes word, het die Konstitusionele Hof nie gesê nie behalwe dat dit iets met onregmatigheid te doen gehad het. Watter tersaaklike reël nie met die Handves in ooreenstemming is, is ook nie geïdentifiseer nie.

Op die keper beskou, wat die Hoogste Hof van Appèl "verkeerd" gedoen het, was om by toepassing van die onregmatigheidskriterium van Ewels nie die grondwetlike waardes in ag te neem nie. Met ander woorde, dit was nie ' $n$ geval van die versuim om die gemenereg te ontwikkel of aan te pas nie, dit was die versuim om by die toepassing van 'n dood goeie reël relevante oorwegings in ag te neem. Dus: Carmichele het nie oor artikel 39(2) gegaan nie maar oor 'n "verkeerde" feitebevinding van die Hoogste Hof van Appèl. As die Konstitusionele Hof die vraag voor hulle in hierdie terme sou geformuleer het, sou dit nie 'n grondwetlike vraag gewees het nie en sou ek nie 'n uitspraak oor die onderwerp gelewer het nie. ${ }^{54}$

Ten besluite. Regters is nie veronderstel om buite die hof kommentaar oor hulle eie of kollegas se uitsprake te lewer nie; en veral nie oor hoër howe nie. Die kritiek en geskinder waarna u moes luister, was egter (in die woorde van Mikro

54 Phoebus Apollo Aviation v Minister of Safety and Security 2003 (2) SA 34 (KH). 
se Meraai) in liefde. Wat aan u voorgedra is, is ook sonder benadeling van regte. Ek mag enige tyd van siening verander. En ek sal. Sonder aanmaning.

En wat is die gevolgtrekking? Dit is dat die nuwe era wat ons betree het besondere eise aan regsprekers stel. Aan die een kant is die oorheersende gesag van die Grondwet; en aan die ander kant is die oorheersende krag van die Grondwet - die Grondwet is weerskante, alle kante. Maar die grense deur die Grondwet gestel, is nie van lemmetjiesdraad nie; ook nie van rubber nie. 'n Vrye regterlike diskresie is nie ' $n$ grondwetlike waarde nie. ${ }^{55}$ Regsonsekerheid is ook nie een nie. Omdat die Grondwet 'n nuwe kultuur daarstel, is dit dikwels moeilik om die inhoud en grense van die kultuur te bepaal. Nogtans moet die Grondwet steeds realisties benader word. En dit gaan tot meningsverskil bly lei.

Die Grondwet verblind nie; dit belig die regslandskap. Dit bied nie 'n skans vanwaar die gemenereg aangeval kan word nie; dit verskans regte. Artikels 39(2) en 173 plaas nie 'n kapmes in die hand van die regter om die reg te onthoof of te ontman nie; eerder verskaf dit modelleerklei waaruit 'n kunswerk gebou moet word wat die hitte van die bakoond sal kan weerstaan.

55 Brisley v Drotsky par 25. 


\section{Bibliografie}

Bork Tempting of America

Bork RH The Tempting of America: The political seduction of the law (Free Press New York 1990)

Davis Democracy and Deliberation

Davis D Democracy and deliberation : transformation and the South African legal order (Juta and Co Kenwyn 1999)

Hahlo en Kahn SA Legal System and its Background

Hahlo HR en Kahn E The South African Legal System and Its Background (Juta Kaapstad 1968)

Hawthorne 2004 THRHR 294

Hawthorne L "Closing of the open norms in the law of contract" 2004 THRHR 294

Haynie Judging Black and White

Haynie SL Judging Black and White: Decision Making in the South African Appellate Division 1950-1990 (P Lang New York 2003)

Huber Liability: The legal revolution and its consequences

Huber PW Liability: The legal revolution and its consequences (Basic

Books New York 1990)

Holmes Common Law

Holmes OW The Common Law (Belknap Press of Harvard University Press Cambridge, Massachusetts 1963)

Martino Trademark dilution

Martino T Trademark dilution (Oxford University Press Oxford 1996)

SALR Application of the Bill of Rights

SA Law Commission Report on the application of the Bill of Rights to criminal procedure, criminal law, the law of evidence and sentencing (Project 101) May 2001 


\section{Snyman Strafreg}

Snyman CR Strafreg 4e uitg (Butterworths Durban 1999)

Tladi SAPR 473

Tladi D "One step forward, two steps back for constitutionalising the common law: Afrox Health Care v Strydom" 2002 SAPR 473-478

Van der Walt 2003 SAJHR 517

Van der Walt J "Horizontal application of fundamental rights" 2003 (19) SAJHR 517

\section{Register van wetgewing}

Algemene Regswysigingswet 76 van 1963

Constitution Act 1982 (Kanada)

Grondwet van die Republiek van Suid-Afrika 1996

\section{Register van hofsake}

Afrox Healthcare Bpk v Strydom 2002 (6) SA 21 (HHA)

Amod (born Peer) and another $v$ Multilateral Motor Vehicle Accidents Fund [1999] 4 All SA 421 (A)

Amod (born Peer) and another v Multilateral Motor Vehicle Accidents Fund 1998 (4) SA $753(\mathrm{KH})$

Blaauwberg Meat Wholesalers v Anglo Dutch Meats (Exports) 2004 (3) SA 130 $(\mathrm{HHA})$

Bock v Duburoro Investments (Pty) Ltd 2004 (2) SA 242 (HHA)

Brisley v Drotsky 2002 (4) SA 1 (HHA)

Carmichele v Minister of Safety and Security 2001 (4) SA $938(\mathrm{KH})$

Carmichele v Minister of Safety and Security 2001 (1) SA 489 (HHA)

Dagenais v Canadian Broadcasting Corp 25 CRR 2d 27 (SCC)

Du Plessis v De Klerk 1996 (3) SA 850 (KH)

Ex parte Minister of Safety and Security: In re S v Walters 2002 (4) SA $613(\mathrm{KH})$ Geldenhuys v Minister of Safety and Security [2002] 3 All SA 82 (K) 
Heyns $v$ Venter 2004 (3) SA $200(\mathrm{~T})$

Ismail $v$ Ismail 1983 (1) SA 1006 (A)

Janse van Rensburg v Grieve Trust 2000 (1) SA 315 (K)

Jayija v MEC for Welfare 2004 (2) SA 611 (HHA)

Jayija v MEC for Welfare [2003] 2 All SA 223 (HHA)

Juglal NO v Shoprite Checkers (Pty) Ltd [2004] 2 All SA 268 (HHA)

Juglal NO v Shoprite Checkers (Pty) Ltd 2004 (5) SA 258 (HHA)

Khumalo v Holomisa 2002 (5) SA 401 (KH)

Merck en Co Inc v Generics (UK) Ltd [2003] EWHC 2842 (Pat)

Miliangos v George Frank (Textiles) Ltd 1976 AC 443 (HL)

Minister of Safety and Security v Carmichele 2004 (3) SA 304 (HHA)

Minister van Justisie v Ewels 1975 (3) SA 590 (A)

National Media Ltd v Bogoshi 1998 (4) SA 1196 (HHA)

Pakendorf v De Flamingh 1982 (3) SA 146 (A)

Pearl Assurance Co Ltd v Union Government 1934 AD 560

Price Waterhouse Coopers Inc v National Potato Co-op Ltd [2004] 3 All SA 20 (HHA)

Phoebus Apollo Aviation CC v Minister of Safety and Security 2003 (2) SA 34 $(\mathrm{KH})$

Robinson v Volkes NO 20042 All SA 61 (C)

Ryland v Edros 1997 (2) SA 690 (C)

S v M 2004 (3) SA 680 (O)

$S$ v Safatsa 1988 (1) SA 868 (A)

$S v$ Thebus 2003 (6) SA $505(\mathrm{KH})$

SA Forestry Co Ltd $v$ York Timbers Ltd (HHA-uitspraak 9 Sep 2004)

SA Sentrale Ko-op v Shifren 1964 (4) SA 760 (A)

SAUK v O'Malley 1977 (3) SA 394 (A)

Soobramoney $v$ Minister of Health KZN 1998 (1) SA 765 (KH)

Stott $v$ Johannesburg Country Club and Another 2003 (4) SA 559 (T)

Suid-Afrikaanse Nasionale Trust en Assuransie Maatskappy Bpk v Fondo 1960

(2) SA 467 (A) 
Villiers NO v BOE Bank Ltd [2004] 2 All SA 457

Villiers NO v BOE Bank Ltd 2004 (3) SA 1 (HHA) 